\title{
The biopolitics of 'food insecurity': towards a critical political ecology of the body in studies of women's transnational migration
}

\author{
Megan A. Carney ${ }^{1}$ \\ Arizona State University, USA
}

\begin{abstract}
In this article, I utilize a political ecology of the body (PEB) approach to analyze women's transnational migration and their experiences with 'food insecurity.' I situate this analysis within a tradition of feminist political ecology, seeking to advance a 'postcolonial intersectionality' that is attentive to gender, race, and class as axes of power and difference, and also to markers of citizenship or lack thereof, including 'illegality.' I argue that the ideologies behind these axes of power obscure the very social processes in which power is constituted, those that allow an unevenness to ecological suffering, specifically at the locus of the migrant women's body. I suggest that by applying a PEB framing to analyze the personally necessary activities of eating and feeding, we are able to elucidate material and health disparities characterizing transborder ecologies. Thus, I delineate the biopolitics of 'food insecurity': a contest over nutritional resources in which migrant bodies are subjected to the disciplining techniques of neoliberal capitalism, as migrants also subvert the conditions of this environment through embodied modes of collective resistance.
\end{abstract}

Keywords: political ecology of the body, feminist political ecology, intersectionality, illegal migration, food insecurity, biopolitics

\section{Résumé}

Dans cet article, j'utilise une écologie politique du corps (political ecology of the body, PEB) pour analyser la migration et d'expériences transnational des femmes avec «linsécurité alimentaire». Je situe cette analyse dans une tradition de l'écologie politique féministe, qui cherchent à promouvoir une «intersectionnalité postcoloniale». Ce est attentif aux axes de la puissance et de la différence - sexe, la race et la classe - et également aux marqueurs de la citoyenneté ou de l'absence de celui-ci, y compris «l'illégalité». Je soutiens que les idéologies derrière ces axes de pouvoir masquent les processus sociaux dont le pouvoir est constitué, et qui permettent une irrégularité de la souffrance écologique, en particulier au niveau du locus du corps des femmes migrantes. Je suggère que, par l'application d'un encadrement de PEB à l'analyse des activités personnellement nécessaires de l'alimentation, nous sommes capables de comprendre les disparités matérielles et de santé qui caractérisent écologies transfrontaliers. Ainsi, je délimiter la biopolitique de «l'insécurité alimentaire» : une contestation sur les ressources alimentaires dont les corps des migrants sont soumis à des techniques de discipliner d'un capitalisme néolibéral. Les migrants renversent également les conditions de cet environnement à travers des modes consacrés de résistance collective.

Mots-clés: écologie politique du corps, l'écologie politique féministe, intersectionnalité, migration illégal, l'insécurité alimentaire, la biopolitique

\section{Resumen}

En este articulo, utilizo un emarcado de la ecología política del cuerpo (PEB) para analizar la migración transnacional de mujeres y sus experiencias con 'la inseguridad de los alimentos." Situo este análisis dentro de una tradición de ecología política feminista, buscando avanzar un "postcolonial intersectionality" que está atento no sólo al género, raza, y clase como los ejes del poder y diferencia pero también a las señales de ciudadanía o su falta, incluyendo "ilegalita." Argumento que las ideologías detrás de esos ejes del poder oculten los propios procesos sociales en los cuales el poder esté constituido, y los cuales que permitan la

\footnotetext{
${ }^{1}$ Dr. Megan A. Carney, Postdoctoral Research Associate, Comparative Border Studies Institute, School of Transborder Studies, Arizona State University, Tempe, AZ 85287-6303, USA. E-mail: megcarney "at" gmail.com. I would like to thank UC MEXUS for providing a PhD dissertation grant to conduct this fieldwork, the participants in this research, and the Comparative Border Studies Institute at Arizona State University for supporting the write-up of this article. I am also indebted to Drs. Ann Anagnost, Melissa Caldwell, Teresa Figueroa, Leila Rupp, Susan Stonich, and Casey Walsh for helping me to think through my findings, and to Josiah Heyman and the four anonymous reviewers from the Journal of Political Ecology for offering valuable additional insights.
} 
desigualdad de sufrimiento ecológico, específicamente al sitio del cuerpo de la mujer migratoria. Sugiero que con la aplicación de un emarcado PEB para el análisis de las actividades necesarias y personales como el alimentarse y el comer, podamos aclarar las desigualdades materiales y de salud caracterizando ecologías transfronterizas. Entonces delineo los biopolíticos de "food insecurity": una contestación sobre los recursos nutricionales en los cuales los cuerpos de los migrantes estén sometidos a las técnicas disciplinarias del capitalismo neoliberal, mientras los migrantes subviertan las condiciones de eso ambiente por modos incorporados de resistencia colectiva.

Palabras claves: ecología política del cuerpo, ecología política feminista, intersectionality, ilegalita, inseguridad de los alimentos, biopolíticos

\section{Introduction}

Historically, political ecologists have primarily been concerned with understanding configurations of power and the uneven distribution of costs and benefits associated with changes in the environment (Bryant and Bailey 1997; Peet and Watts 1996). Increasingly, they have argued that the terrain of human health must be acknowledged as an 'environment' in its own right, thus necessitating that we examine (un)healthy bodies within the wider ecological context of (un)healthy landscapes (Baer 1996; Guthman 2011; Hayes-Conroy and Hayes-Conroy 2013). King (2010: 40) suggests that a political ecology of health promises to "[1] generate new insights into the political economy of disease, [2] interrogate health discourses produced by actors and institutions, and [3] show how health is shaped through the relationships between social and environmental systems..."

Hayes-Conroy and Hayes-Conroy (2013:82) offer a slight revision to the political ecology of health in discussing a methodological framework that they allude to as the political ecology of the body (PEB). They suggest that this framework:

...facilitates an analysis of the always affective/emotive body that is simultaneously structural and post-structural, material and discursive; it is a framework that offers attentiveness to the rigidities of our socio-political world and yet remains open to the new possibilities that affective encounters may allow.

Thus, PEB integrates a political ecology of health while also underscoring the affective and emotional dimensions of extant political ecological concerns, including "...conflicts over resource access/use, challenges of environmental governance, and our human-environment relationships and struggles more broadly" (Hayes-Conroy and Hayes-Conroy 2013: 85).

This article utilizes the PEB framing to analyze and interpret 'food insecurity', particularly as this global problem shapes the experiences and subjectivities of women migrating from the global South to global North. As PEB represents a relatively recent direction within the broader theory of political ecology, there remains much work to be done in exploring how PEB may be used to address some long-standing concerns of political ecological analyses.

Many formal definitions exist for 'food insecurity' and its counterpart 'food security', but at its most basic level the former concept refers to a situation in which people lack enough food to meet basic needs. Yet the ontological basis for the concept of 'food insecurity' stems from an ongoing politics of knowledge that increasingly attempts to apply scientific understanding to what are indeed political-economic or social problems and all the while dehumanizing those who suffer. ${ }^{2}$ Nevertheless, global prevalence of the problem defined as 'food insecurity' suggests that current industrial modes of food production, distribution, and consumption are failing to meet the nutritional needs of populations throughout the world. Many have alluded to this situation as an environmental or ecological crisis (Holt-Giménez and Patel 2009; IAASTD 2009; Katz 2008; McMichael 2009). The conditions of 'food insecurity' pose numerous risks to health, some more severe than others; by extension, 'food insecurity' may be considered a health problem with political and economic

${ }^{2}$ For a deeper discussion of the subjective and objective dimensions of 'food insecurity' and 'food security', see Carney (2011). 
dimensions, both in its genesis and through its appropriation by multilateral organizations, state agencies and NGOs.

This article presents findings from ethnographic fieldwork conducted in southern California to explore how undocumented Mexican and Central American migrant women living in the United States experience and contest the biopolitics of food insecurity. My analysis of these findings is informed by a feminist epistemology that views asymmetrical relations of power between the global South and global North, and the structural disparities that exist within United States society, as both products and instruments of neoliberal capitalism that enable the accumulation of capital while also undermining human dignity, rights, and desires for autonomy (Agustin 2003; Boris and Salazar Parreñas 2010; Chang 2000; Rosas 2012; Zavella and Segura 2007).

\section{Feminist political ecology and postcolonial intersectionality}

Feminist political ecology (Neumann 2005; Rocheleau et al. 1996) examines how women interpret and respond to oppressive governance over resources while also demonstrating the "multiple and contemporary ways access to and control of natural resources are gendered," (Mollet and Faria 2013:116). Mollet and Faria (2013) critique feminist political ecology for failing to account for race as a critical variable that articulates with gender in shaping resource access. These authors argue for a revision through a lens of 'postcolonial intersectionality,' which they define as "a concept that moves beyond US based racial and gender hierarchies to acknowledge the way patriarchy and racialized processes (including whiteness) are consistently bound up in national and international development practice" (2013:117).

In this article, I propose to advance 'postcolonial intersectionality' by bringing attention not only to gender, race, and class as axes of power but also to markers of citizenship or lack thereof, as these are inscribed onto the body. I argue that the ideologies behind these axes of power obscure the very social processes in which these power relations are embedded and constituted and which have allowed for an unevenness of ecological suffering, specifically at the locus of migrant women's bodies.

\section{3. 'Food insecurity' as differential governance: race, class, gender and citizenship}

State surveillance of those who are suspected to lack legal authorization in the United States has become increasingly pronounced in the post-9/11 context (Coleman and Kocher 2011), yielding to a constellation of "sites of exception" (Fassin 2011:217) that strip certain lives of political rights, rendering them into the realm of "bare life" (Agamben 1998). Gonzales and Chavez (2012: 255) link the increasing ubiquity of surveillance, random detentions, and deportations of migrants in the United States to a "biopolitics of citizenship and governmentality." They allude to the prominence of the body as a site of exercising this biopolitics, of restraining mobility, and of "[constructing] subjective understanding" (p. 267) of what it means to be an undocumented ('illegal') person.

'Illegality' has proven a powerful social construct in combining 'syndemically' (Singer 2009) with other structural vulnerabilities in producing health disparities (Mendenhall 2012; Quesada, et al. 2011; Willen 2012). De Genova (2002) contends that migrant 'illegality' is predicated on the erasure of legal personhood, marooning the individual into "a space of forced invisibility, exclusion, subjugation, and repression" (p. 427). Simultaneously a juridical status, a sociopolitical condition, and a way of being-in-the-world (Willen 2007), 'illegality' permits an individual to participate in some aspects of social life but not others (Coutin 2007; Gonzales and Chavez 2012).

Although feminist political ecology has highlighted the gendered implications of uneven resource distribution (Rocheleau et al. 1996), I align with critical medical anthropologists and critiques from those within feminist political ecology in arguing for an intersectional analysis that includes the experience of 'illegality' as an axis of barriers to resource access, resulting in embodied disparity (Willen et al. 2011). James Quesada, Laurie Kain Hart and Philippe Bourgois (2011) allude to "the embodiment of subordinated status" experienced by undocumented migrants as they confront conditions of structural and symbolic violence (p. 342). Vulnerabilities experienced vis-à-vis constraints on nutritional needs "[have] very real consequences: shorter lives subject to a disproportionate load of intimate suffering" (Quesada, et al. 2011:351). It is also 
important to highlight how migrants subvert such structural injustices, even if in limited ways (Zavella 2011; Zavella and Segura 2007).

While a rich critical medical anthropology literature examines the relationship of migrant health to illegality (e.g., Fassin 2011; Holmes 2012; Horton and Barker 2009; Horton and Barker 2010; Larchanche 2012; Quesada et al. 2011; Sargent and Larchanche 2011; Willen, et al. 2011), there has been scant attention to food insecurity as an important aspect of illegality that has repercussions for health. Food insecurity has not been recognized as a legitimate basis for migrants seeking authorized entry into countries like the United States, yet food insecurity is often foregrounded in women's narratives of migration. The precariousness of 'illegality' experienced by many unauthorized migrants also makes it increasingly difficult to avoid food insecurity while living in the United States, while undergoing other forms of systematic oppression that articulate with race, class, and gender. Food insecurity and infringements of access to food may weigh especially heavily on migrants' personhood, in symbolizing the denial of personal aspirations to achieve upward mobility. Thus, impediments to food access while in the process of migrant settlement represent another site of social injury. As Brownell (2005:256) notes, "hunger could refer to 'the lack of fulfillment of personal aspirations and desires' as much as to real malnourishment (Kahn 1986: 122)."

In the following pages, I outline a biopolitics of food insecurity that exists as one dimension of the biopolitics of citizenship and governmentality, as follows:

1) pre-migration experiences with food insecurity

2) post-migration encounters with food insecurity

3) post-migration strategies of collective resistance.

I begin by describing food insecurity as it influences women's decisions to migrate to the United States. Next I describe how certain markers of social difference (i.e., gender, race, class, immigration status) articulate with economic and socio-political barriers to render a differential governance of migrant women's bodies. I illustrate this through presenting migrant women's efforts to obtain, balance, and allocate nutritional resources. I argue that these food provisioning processes are regulated by disciplining techniques of neoliberal capitalism that monitor and restrict where the body trespasses, what trespasses the body, and one's range of affective experiences. The final portion of my findings highlights women's embodied strategies of collective resistance: ways of contesting both external and embodied environmental disparities through what they describe as cuidarnos en la comida (caring for ourselves through food). I then offer a synthesized analysis that examines the full set of intersecting political ecologies of food that undergird these findings to argue that 'the body' is both the agent and canvas of embodied material practices, coupling everyday social and ecological cycles and flows (Heyman 2004).

\section{Methodology}

Santa Barbara County (the site of my ethnographic fieldwork) is located on the coast of southern California and lies approximately 100 miles northwest of the city of Los Angeles. In 2010, the county's population was 42.9\% Hispanic, and totaled 423,895 people (Bureau of Population Statistics 2010). In 2010, $18.0 \%$ of residents were living below the federal poverty line (up from 11.9\% in 2007), and of the county's population living at $-200 \%$ or below the federal poverty level, 69\% were Hispanic (Bureau of Population Statistics 2010).

Santa Barbara County is an extraordinarily expensive place to live. Local real estate values exceed even the median values for the rest of California; the median home price in the county in August 2011 was US\$278,500 (down from \$353,000 the year before). ${ }^{3}$ Noting the high cost of living, the Housing Authority of Santa Barbara County adjusted the local poverty level to $\$ 53,700$ for a four-person household, substantially above the federal figure of \$22,050 (Housing Authority of Santa Barbara County 2011). Tourism, agriculture,

\footnotetext{
${ }^{3}$ Comparatively lower home prices in North County bring down the average for the entire county. South County home prices are disproportionately higher. Median home price in the city of Santa Barbara in August 2011 was \$662,500. See http://www.dqnews.com/Charts/Monthly-Charts/CA-City-Charts/ZIPCAR.aspx
} 
and construction rank among the region's principal economic activities; these industries employ several thousand migrants annually as hotel housekeepers, janitors, restaurant cooks, gardeners, farmworkers, and construction workers.

During the course of my fieldwork, Santa Barbara County also had the second highest rate of food insecurity in California (39\% of low-income households) (California Health Interview Survey 2009). In 2011, the largest hunger-relief organization in the region reported that more than one-quarter of the county's population sought emergency food assistance. Although food insecurity is a complex problem, the particular issue in Santa Barbara County is the high cost of housing, and relatively low incomes earned through an economy centered on the availability of low-wage labor.

The data I present in this article are derived from 20 months of ethnographic fieldwork that I conducted between 2008 and 2011 with Mexican and Central American migrant women (N=25) and private food assistance programs operating in Santa Barbara County. This research focused on the lived experiences of migrant women and interventions by NGOs for food insecurity and 'diet-related diseases.' Recognizing the challenges of connecting with undocumented migrants for the purposes of research (Himmelgreen et al. 2007; Pérez-Escamilla et al. 2010), I chose to conduct outreach through community organizations that regularly provided services to the region's low-income, predominantly migrant population. Sites of recruitment included private food assistance distributions and parent meetings at Head Start preschools. Women of age 18 or older were eligible to participate in this research if they had migrated from Mexico or Central America, and also had previous experience utilizing some form of food assistance while in the United States, thereby suggesting that they had encountered issues with food access.

Among the 25 migrant women I recruited as key informants, ages ranged from 24 to 60 years (mean age of 38). The majority of women had migrated to the United States from sending states in Mexico including Guerrero, Michoacán, and Oaxaca, although two of the women were originally from Central America (Honduras and Guatemala). Five of the women had obtained formally authorized status (Plascencia 2012) while living in the United States, but most (20 out of 25) were sin papeles (i.e., informally authorized or undocumented). ${ }^{4}$ Women's length of residency in the United States spanned from three months to 30 years. Only one of the women did not have children of her own, but even she was in the process of adopting through familial networks in Mexico. Of the 25 women, 11 had full- or part-time employment, while the remaining 14 were underemployed $(n=9)$, supported by a spouse $(n=4)$, or on disability $(n=1)$. Underemployed in this context implies that individuals would prefer more employment but do not have it. Two of the women reported obtaining post-secondary training at a university or vocational school prior to coming to the United States, while all of the other women had attended only primary school in their countries of origin. Sixteen of the women were married or living with a spouse, four had never been married, and five were separated or divorced.

Semi-structured and life history interviews, dietary surveys, participant observation, and focus groups served as the primary instruments of data collection. I conducted one round of dietary surveys with each woman once at the beginning and again toward the end of fieldwork, consisting of 24-hour recalls, food frequency surveys, and the USDA 18-item Household Food Security Survey. As part of collecting women's life histories, I included a list of questions that specifically addressed food memories, knowledge, and preferences for the purpose of evoking "the food story of their lives" (Hubert 2004). The women and I decided on interview times and locations (neighborhood parks, women's homes, schools and community centers) over the phone. As a participant-observer, I documented interactions between staff and volunteers of NGOs with migrant women, particularly with regards to the manner and content of interventions, and I accompanied women in some of their daily activities such as grocery shopping, informal work, picking up kids from school, and preparing meals. Toward the end of fieldwork, I organized three focus groups by women's area of residence. Focus groups met a total of three times each, and were facilitated by an experienced moderator who was from a Mexican immigrant family herself and affiliated with a prominent nonprofit that primarily served the local Latino community. All interview and focus group interactions were

\footnotetext{
${ }^{4}$ Plascencia (2012) argues that the terms in popular use to describe migration to the U.S. are insufficient, for they do not account for the ways in which most of this migration is authorized in one form or another. Thus, he proposes the terms 'informally authorized' and 'formally authorized' to replace 'undocumented' and 'documented.'
} 
conducted in Spanish. I recorded these interactions with women's verbal consent and transcribed the recordings with the assistance of native Spanish speakers. The portion of the transcriptions that appear in this article I have translated from Spanish into English.

Throughout this article, I employ the term 'migrant' as opposed to 'immigrant' to highlight the nuanced circumstances equivocating some women's trajectories of migration and to recognize that not all migrants desire to become permanent residents or citizens of the United States (Zavella 2011). I also use the term 'transborder' to denote the myriad barriers - aside from those determined by one's legal status - facing migrants in the United States. In addition to geopolitical borders, a transborder perspective emphasizes other sites of inclusion and exclusion mediated by material, economic, social, symbolic, and institutional forces (Stephen 2007).

\section{The biopolitics of 'food insecurity'}

Similar to Jonathan Xavier Inda's (2002) observation of the denial of prenatal care to undocumented migrant Mexican women as representing a form of biopower that disallows life in order to foster life, I argue that the everyday, lived experiences of migrant populations with meeting nutritional needs reflects how globalizing processes render an uneven governance of life, thereby constituting a biopolitics of 'food insecurity.' In the following section, I demonstrate how food scarcity significantly influences women's migration decisions. I then discuss various experiential, lived aspects of post-migration changes to diet and how these are inscribed at the scale of women's bodies.

\section{Food scarcity in narratives of migration}

Boehm (2012) accounts for the "intimate relations" shaping women's migration from Mexico to the United States, that women in my research frequently framed through the language of feeding and eating. The claim that "Allá no tenemos nada que comer" ([Back there] we had nothing to eat) surfaced as a common refrain in women's migration narratives. Specifically, women in my research recalled the daily struggle (la lucha diaria) surrounding the personally necessary activities of feeding and eating in their home countries and how constraints on alimentarse (to feed) factored significantly into women's decisions to migrate.

At the same time that food scarcity and disruptions to the provision of 'caring labor' impel women to migrate, shifts in the United States labor market in the latter half of the twentieth century have also created a demand for cheap, 'caring,' reproductive labor imported from elsewhere. Migrant women disproportionately fill these jobs. In my own fieldwork, I observed men employed primarily in construction or landscaping, or sometimes in horticulture or food service, whereas women worked in the service economy as hotel housekeepers, house cleaners, or babysitters. This gendered, classed, and racialized division of labor that relegates Latino migrants to low-wage jobs is by no means a recent development but traces back to Anglo settlement in California in the late 1840s (Camarillo 1979). While the women in my research who were married or benefitted from the collective pooling of financial resources in multiple earner households, forms of part-time employment in the service economy provided supplementary income. In contrast, women without these other means of support worked 50 to 70 hours per week and struggled disproportionately with paying for rent, utilities, food, and other household expenses. Women from both types of households managed and distributed earnings to meet the reproductive needs of family members both in the United States and in home countries. In several instances, being able to care for relatives abroad was predicated on earning a wage through the provisioning of 'caring labors' in the United States, an arrangement that has been of central concern to feminist analyses of globalization (see for example Browner and Sargent 2011; Chavkin and Maher 2010; Colen 1995; Parreñas 2001).

"There isn't enough money..."

Linda could not afford to buy food in her home state of Michoacán in Mexico. She recalled relying on a diet of básicos (basic foods): 
If one desires fruit or vegetables, one must buy them and our parents didn't have enough money to buy. We ate almost no meat because it was very expensive. So we ate beans, chilies, tortillas; this is what one ate most because we didn't have money for fruits and vegetables. ${ }^{5}$

Her father cultivated a small portion of land around their home, and her mother tended to fruit trees; these activities provided an important, though inconsistent source of food for her family.

Linda was expected to clean the house, launder clothes, and iron for others in her town. She did not attend school for long because her parents needed her and her siblings to work. At the age of 12, Linda began working in el campo (the fields) "cortando la fresa" (harvesting strawberries), then broccoli, and then tomatoes. Even with the combined income among her siblings, they were never able to accumulate enough money to buy nutritious food ("no alcanza dinero para comida nutritiva"). She mentioned that her mother died of diabetes, relating her death in part to a diet lacking in quality sources of nutrition.

Structural adjustment programs in the latter half of the twentieth century as well as 'free trade' agreements such as NAFTA have had significant repercussions for the subsistence practices of rural communities in Mexico and Central America. Households no longer produce for subsistence but are dispossessed and inserted into the market economy, a market that simultaneously makes food increasingly a commodity to the detriment of dietary health and material security of resource-poor households. As households become further proletarianized, especially in terms of consumption - 'consumer proletarianization' (Heyman 1994) - they must purchase commodity inputs from the capitalist economy, yet coupled with structural shifts in the global food system, people also consume more industrially-grown food.

In her early 20s, as she and her husband anticipated their first child, Linda decided to migrate to Carpinteria, a small town on the southern coast of Santa Barbara County where her husband had been working in the local flower nurseries. Her husband paid an estimated \$1,200 to a coyote for each of their crossings. When I meet Linda, she is 33 years old and living with her husband and their three children, ages 12,7 , and 5 . She laments that they frequently lack the resources to provide a balanced diet to her children. To economize on groceries, she will drive to a city forty minutes south where she finds foods at a lower price. However, much of the food in her household she procures from charitable food pantries because "there [isn't] enough money to buy [food]" ("No hay suficiente dinero para comprar"). Although her family never experiences hunger, she notes that the food they consume is often lacking any nutrition. In general, however, she describes her access to food in the United States as "better than in our town in Mexico" ("mejor que nuestro pueblo").

It is noteworthy to mention that Santa Barbara County is one of the most agriculturally productive counties in the state of California, constituting a US\$1 billion industry that also employs thousands of migrant farmworkers. The existence of any level of 'food insecurity' in a region with so much agricultural productivity seems oxymoronic, at least at first glance. However, given California's role in the global food system as being a 'breadbasket' for the world, these findings are less surprising. A recent study estimated that more than $98 \%$ of the crops cultivated in Santa Barbara County were for export to areas outside of the county (Cleveland et al. 2011).

\section{"I fight for their wellbeing"}

In the case of Malena (46, from Guerrero), her decision to migrate was informed by tensions with her husband that obstructed her ability to feed her children. Malena's husband had migrated to work in California following the birth of their firstborn: "He left me with my child when he was only two months old; he came here. He had been coming here since 1984 . So he already knew the country well..." ${ }^{6}$ Yet after years of sending remittances home to his family, he suddenly stopped all forms of communication. When I meet Malena, she is working 70 hours per week as a hotel housekeeper, and living with her youngest daughter.

\footnotetext{
5 "Allá si deseabas fruta, verdura porque no teníamos el dinero suficiente dinero para que nuestros padres compraran. No carnes porque era muy cara. Entonces comíamos frijol, chile, tortillas, es lo que mas comía uno, porque no teníamos para frutas y verduras."

6 "El me dejó con mi niño, tenía él dos meses, él se vino para acá ... él se estaba viniendo, él tenía tiempo viniendo hacia acá desde el 84 ... entonces él ya conocía aquí el país cómo era y todo..."
} 
Three of her children (ages 13, 14, and 18) are still living in Guerrero with their grandmother and she has since divorced her husband. Although Malena conveys tremendous grief in being far from her children, she rationalizes her decision to migrate to the United States by conveying that in Mexico she was no longer able to fulfill her responsibilities as a mother. Her husband had forfeited his obligations - both emotional and material - to the family, and she had accumulated a debt from needing to borrow money for food purchases:

The debt that I had there... this is what was worrying me. So I thought and said, 'When I am going to pay this money?' So, I thought and thought only of this, and I had faith and hope that I'd arrive here [in the United States]. Ultimately I was thinking of work because I came to work, to find a job. ${ }^{7}$

Malena frequently becomes distressed when talking about her children from whom she is estranged; she wants them to know that "esforzarme para dejarlos bien..." (I fight for their wellbeing), "I hope to do something better for them because they are young and they still need me." ${ }^{8}$ Her children express curiosity about her life and regularly probe Malena about when they will be able to visit her in the United States.

Further compromising Malena's ability to provide food for her household was a lack of stable housing in Santa Barbara. The first time I visited Malena at home, she was living in a small apartment near the train station with two other families. When I visited Malena at this residence some weeks later, she had been abruptly evicted by one of the families. A teenage girl greeted me at the door and shouted to her mother in the back of the apartment to ask if Malena was still living there. Her mother yelled down to explain that she had moved. Confused, I called Malena on her cell phone. She explained that the manager's brother had wanted the room that she and her daughter were occupying. He offered to move their things to another room in the downtown area, some miles away. This had all transpired the night before. A few months following Malena's relocation, she complained to me of issues with the "señora" at her new residence, alluding to a possible need to move again within the next couple of months. These types of sudden disturbances to one's living situation required women in my research to make constant adjustments to their everyday lives and often on a regular basis. Being displaced from one's home required finding alternative housing, and quickly, often implying that more of the household budget be subtracted from 'flexible' items such as food, to go toward rent. Malena would regularly complain, for instance, about sometimes needing to feed her daughter fast food because her many hours at work deprived her of the time to prepare healthy meals. I revisit this theme in a later section of this article when discussing women's perspectives on time- and energy-saving food provisioning practices.

Compared to households with multiple earners, women without other sources of financial support had relatively less material security or flexibility in their schedules to accommodate reproductive labors. Constraints on urban development in Santa Barbara and the related lack of affordable housing - a limited good - subjected low-income residents to a life of perpetual instability and material insecurity. There is a tension here when looking at the array of conditions that constrain urban development: the 'aesthetic' of Santa Barbara that invokes its Spanish missionary past and is preserved for tourists; interest by wealthier residents in preserving 'open space' for recreational purposes (the maintenance of which contributes to the value of their own real estate); and agriculture (both industrial and small-scale, organic) (Cleveland et al. 2010) which faces its own constraints especially in terms of scarce ecological resources. Also noteworthy here is that migrant labor is central to maintaining all of the above uses of this space.

\section{Post-migration changes to eating and feeding}

While women in my research associated migration with improved capacity to nourish others through food, to many women's disappointment, challenges with food insecurity and resource scarcity persisted post-

\footnotetext{
7 "La deuda que yo tengo porque allá en el pueblo cada mes es un pago de rente... al siguiente mes es otro pago... y es a mí lo que me estaba preocupando ... pues yo pensaba y decía "cuando voy a pagar ese dinero"... Pues, pues yo pensaba pues yo últimamente yo pensaba en eso yo solamente pensaba yo en mi mente decía yo tengo la fe de que yo voy a llegar al lugar de que yo tengo que ir, tengo la esperanza de que voy a llegar a ese lugar ... y lo yo últimamente yo pensando en el trabajo porque como yo venía a trabajar yo inclinada en buscar un trabajo..."

8 "Yo espero hacer algo mejor para ellos porque ellos están chicos todavía necesitan de mi necesitan."
} 
migration. Women described impediments to everyday nutritional needs as tethered explicitly to the experience of 'illegality,' as well as, albeit more implicitly, to class, gender, and race.

Pilar (28, from Guatemala), a mother of three, had only been living in the United States for a few weeks when we first met. She was several months pregnant and living with a few friends who were helping her financially until she was ready to find employment. As a way of reciprocating with her housemates, Pilar managed all aspects of food in the household, from grocery shopping to preparing meals. Despite her recent arrival the United States, she had already become familiar with many of the discourses circulating about changes to diet in migrant communities, also observing several of these changes firsthand. She explained:

Sometimes there is not enough money to give [loved ones] something better to eat. Sometimes they don't eat well because they eat fast food or food that makes them gain weight, that doesn't nourish them. Or they eat something that only fills them for a short time, for the reason that they're busy with their job. People only go to work, back home, and then to work again. Here the time is more rushed. ${ }^{9}$

Despair about the lack of money and time that yielded to undesirable dietary changes, frequently surfaced in my interactions with other women as well. A precarious labor market that exploited workers of unauthorized status compelled many migrants to work multiple part-time jobs, thus posing significant limits on time outside of work. This 'daily struggle' (la lucha diaria), as women termed it, consisted of constraints on household food budgets, increasing costs of life-renewing resources, socio-political conditions that prevented women from accessing certain social services, social norms that interfered with women's attempts to sustain certain cultural traditions such as gathering around meals, and dietary health problems.

Importantly, my fieldwork overlapped with the onset of economic recession, the consequences of which compounded preexisting structural vulnerabilities of low-income, migrant households (Carney 2012). Women from the communities of my research frequently referred to effects of "la crisis" including: reduced hours of employment (i.e., underemployment) and rising unemployment; reduced purchasing power of lowincome households; higher rents, utility costs, fuel costs, and food prices; and the need to become more vigilant - described by women as "economizar" (to economize) - in the management of household resources, including food provisioning.

\section{Economic constraints: buscando las especiales (bargain hunting)}

Many of the women in my research described purchasing foods based on price alone ("el precio más que nada") or turning to comida rápida (fast food). Juliana (38, from Guerrero), for instance, preferred to plan her meals spontaneously around the bargains she found. Everyday, after dropping her children off at school, she visited several stores on foot to survey prices, always "buscando las especiales" (looking for bargains) or "aprovechar las especiales" (to take advantage of specials). She forfeited shopping lists in favor of buying every item on sale. Sometimes she would collect coupons in advance, as without access to a car or someone to drive her, the journey between stores to compare prices was very time consuming.

Only a handful of the women in my research were able to engage in this type of price surveillance, as others were usually putting in the hours at wage-based sites of work. Juliana was temporarily unable to seek employment because she suffered from a hip injury. Although her husband was mostly employed full-time, he frequently withheld his earnings from her for "el tomar" (drinking). She often complained to me about his drinking problem and noted instances of abuse. Whenever Juliana threatened to leave him, however, he'd tell her: "es mi dinero" (it's my money), insinuating that she would not see a dime from him if she left. Sadly, because of her undocumented status, Juliana was afraid to contact authorities when her husband became abusive, as she was also unable to seek any settlement from him in courts if she decided to leave.

\footnotetext{
9 "A veces no hay suficiente dinero para darles algo mejor comida. A veces no se alimentan bien la gente. Comen a veces así comida rápida o lo que pone a uno muy gordo, no nutre. O sea no más lo llena a uno por un rato, tal vez por el tiempo del trabajo. La gente solamente es del trabajo, a la casa, y otra vez a trabajar. Aquí el tiempo es más corrido."
} 


\section{Socio-political barriers: stigmas around welfare and fears linked to illegality}

Olivia (24, from Guerrero) claimed that her family of five only asked for food stamps when they were "experiencing economic problems" ("cuando estamos pasando por problemas económicos"), regardless of having qualifying incomes. As a common belief shared among all of the women I interviewed, enrollment in welfare programs - excluding healthcare - was viewed as socially acceptable only when one was unemployed. In other words, employment negated deservingness of program support, even given eligible incomes. Malena, for instance, who I discussed in the preceding section, did not want to apply for CalFresh (California's rebranding of SNAP, or Supplemental Nutrition Assistance Program, formerly known as 'food stamps') as long as she was working:

I haven't applied for the stamps because I can work...perhaps it's better if I did ask for help...I don't know... it could be good to ask for [food stamps] but as I say, I have work now, right, and I can do it, but perhaps when I can't do [the work] it would be good to apply...or perhaps if I had [all of] my kids here with me [in the U.S.] I would apply...I would have to ask for help then because I would have to pay more in rent [with them around]. ${ }^{10}$

Women explained that if given the option, they would opt for a paying job over receiving benefits, and they regularly linked the latter to disapproval of 'freeloaders' or people who were perceived to abuse welfare. For instance, women often alluded to the questionable moral character of people they knew to have permanent residency or citizenship (a perceived advantage in terms of finding employment) and nonetheless applied for welfare.

Both James Quesada (2011) and Grace Chang (2000) argue how such denigration of welfare users acts as a form of symbolic violence in pivoting people of similar socioeconomic status (but possibly of different race or ethnicity) against one another instead of inciting them to demand entitlements from the state. Findings from my research support and also complicate some of this previous research by suggesting that 'illegality/legality' is another axis of difference along which migrants make assessments about one's moral character. In other words, these women conveyed that having formal status was an advantage that should preclude one's deservingness of benefits.

Among other reasons for abstaining from welfare, women expressed doubts about revealing themselves to state institutions through participation in programs. For instance, Dora (35, from Honduras), a mother of four, did not want to apply for food stamps because her husband believed that by asking for help they would diminish their chances of obtaining papers. ${ }^{11}$ With two of her children still living in Honduras, Dora was very hopeful that her family could be reunited through the documentation process. Husbands frequently discouraged women from applying if they believed enrollment could possibly exclude them from qualifying for formal status. Fearing that husbands may disapprove of enrollment, women sometimes pursued the application process covertly:

It's because we don't want to be a public charge, but yes [in the past] these programs helped us a lot because we didn't have enough. Because I already had my first two [children], [through asking for help] I felt better. But I had to hide this from [my husband] because he didn't approve. $^{12}$ (Juliana, 38, from Guerrero)

\footnotetext{
10 "Yo no he aplicado para las estampillas porque pues digo ahorita yo puedo trabajar... tal vez a lo mejor más allá yo puedo pedir ... no sé... pero pues últimamente sería bueno pedirlas pero digo ahorita yo tengo pues mi trabajo verdad y lo puedo hacer tal vez ya cuando no lo pueda hacer ocurriría mejor a pedir ... o tal vez si yo tuviera mis hijos acá conmigo pues entonces a lo mejor sí los pediría ... pero pues acá yo ya tendría que pedir ayuda porque tendría que pagar más renta por ellos ..."

${ }^{11}$ While previously one could become a public charge and jeopardize the chance of obtaining formal status if utilizing welfare programs, the USDA dismissed this possibility in 2010.

12 "Entonces no queremos ser carga del gobierno, pero sí nos ayudaron bastante porque no teniamos lo suficiente. Como uno si se aguanta pero como yo ya tenía a los dos primeros niños más primer por eso, porque yo me animé."
} 
Women also distrusted programs for requiring so much information as part of the terms of enrollment. Luisa (38, from Michoacán), a mother of two who offered childcare services from her home, desired to detach herself from negative discourse about users of welfare. Instead, she emphasized her preference for work, as she also longed to feel more in control of her own circumstances: "The truth is that I don't like to get [benefits]. I prefer to work but now work is hard to find. Only when there is really need, but the truth is that I really don't like it." ${ }^{13}$ But she also feared that through her enrollment, she might reveal her unauthorized status to authorities:

I'm going to tell you that they ask you for a lot of information. How much money you have, how much you work, how much your husband earns, many things, and the truth is that I don't like it. Right now I need it. I'm going to look for work so I don't have to give away so much information. ${ }^{14}$

Women like Luisa were concerned both for the immediate repercussions of asking for help while lacking formally authorized status, and the long-term consequences of enrollment in welfare if one were to eventually seek permanent residency or citizenship.

\section{Social norms and consequences for food-based sociality}

Carolina (46, from Guerrero) prepares meals for everyone in her household, which includes her husband, daughter, two sons, and grandson. Carolina reports eating fewer daily meals since migrating from Mexico to the United States because she explains that there is less time both to prepare food and to socialize around meals with the family. She cites a devaluation of the "comida," the main meal of the day, and which she used to consume over a long duration with others:

In Mexico we had three meals per day. In Mexico you had a little milk with tortillas that could be for breakfast or lunch. In the afternoon, [you had] your comida, and in the evening, [you had] your dinner. Here no more than one meal and no more than bread and milk in the morning. I think it is because of how busy people are, because one is always out and not at home. $^{15}$

As several other women fondly recounted, and with a tone of nostalgia, the comida had been a time marked for both nourishing oneself and socializing with others. However, as Carolina is unable to invest much time into preparing meals at home, and her children and husband are less available to share in consuming these meals together, she finds fewer opportunities to sustain the tradition of the comida. Carolina's regret about lacking time to prepare and consume meals with others in her family reflected how work-life demands foreclosed these opportunities, a finding resonant with Heyman's (2004: 119) observation that capitalist consumption "comes from and brings about changes in culturally organized time and space."

Although Carolina was presently unemployed, her husband worked in construction and her oldest daughter, aside from attending high school, worked as a cashier at a local grocery store. Prior to the economic recession, Carolina had worked an array of jobs, including as a factory worker, as a dispatcher at the local post office, and in childcare. Exploitation of low-wage workers and the financial need of Carolina's household demanded that relatives be gone for the majority of hours everyday. When her younger children

\footnotetext{
13 "La verdad a mí no me gusta agarrar. No me gusta yo prefiero trabajar. Prefiero pero como ahorita se escasó el trabajo y yo no trabajo. Yo prefiero trabajar, me entiende? No más que a veces la necesidad pero la verdad a mí no me gusta."

14 "Porque te voy a decir te piden mucha información. Si tienes dinero, cuanto trabajas, cuanto gana tu esposo, muchas cosas y la verdad no me gusta a mí. Pues ahorita la verdad necesitaba...Voy a buscar trabajo así no da bastante información."

15 "En México se hace tres por día. En México aunque sea su lechita con tortillas, tan siquiera es un desayuno o almuerzo. En la tarde su comida y en la noche su cena. Aquí no más una comida y no más en la mañana su pan con leche. Yo creo que por la actividad que tiene uno, porque tiene que ir a comer, y no está uno en la casa."
} 
were not in school, they were engaged in either after-school activities or were involved with friends, meaning that they were also away from the home for most hours of the day.

For Carolina, as well as many other women I interviewed, changes to sociality around meals spoke to larger concerns about social isolation. Carolina complained how her children, and youth in the United States in general, did not spend enough time with older generations. While intergenerational socializing was a common practice among her relatives in Mexico, she found youth in the United States lacking in respect toward elders, and she was upset by her own children's preference for hanging out with friends. She noted her disappointment at the fact that her second oldest daughter planned to move out of the house as soon as she turned 18. In Mexico, she explained, youth continued to live with their families for much longer. It is noteworthy that in the erosion of multiple-generation households women do not only perceive the affective relation expressed through conviviality as being at stake, but also the earnings that contribute to a household's material security through resource-pooling activities.

The irregularity with which Carolina's immediate family gathered around meals was particularly painful for her as she reflected on her estrangement from the rest of her extended family. Although she was one of nine children, she had zero contact with her siblings. While growing up, her mother had been the one to enforce "disciplina y orden" (order and discipline) including sociality around meals; Carolina remembered "Teníamos hora de comer" (we had a set meal time). Yet since her mother's death, "No nos acercábamos como antes," (We were not close like before). She was sad to not know the present whereabouts of her siblings, as she recalled how once "éramos una familia unida" (we were a tight-knit family).

Mankekar (2002) suggests that the inability of diasporic populations to recreate the culinary traditions of their homeland poses compromises for the process of cultural reproduction. As migrants encounter the "everyday violence of imposed scarcity, insecurity, and fear" (Quesada et al. 2011:393) associated with unauthorized status, low wages, and racial discrimination in the United States, they find it increasingly difficult to meet the basic nutritional needs of their families much less to recreate sociality around mealtimes.

"Junk food is what makes us sick"

Natalia (48, from Oaxaca) grew up with an abundance of fresh, nutritious foods in rural Oaxaca. Her family also enjoyed fresh seafood, as her father was a fisherman, and they exchanged some of this seafood for fresh produce through relations of reciprocity with relatives who were farmers. In contrast, Natalia began eating comida chatarra (junk food) when she arrived to the United States, a behavior that she had since abandoned but could not control among her children. Her son for instance, who had suffered from a rare form of cancer at the early age of 5, consumed pizza and burger lunches supplied everyday at his school, much to the dismay of his especially vigilant mother. She explained,

I don't like junk food. I fight with [my son] because I prefer that he'd eat a plate of lentils, [for example], rather than a burger. The school only gives burgers or pizza to the children. So I prefer that in my house, [he eats] rice with chicken, lentils, or a piece of fish with salad. ${ }^{16}$

In addition to worrying about management of her family's diet, Natalia had struggled as the sole wage earner in her household since her arrival with her four young children to the United States twenty years before, having fled a physically abusive husband in Mexico. Women like Natalia perceived an abundance of readily available comida chatarra in the United States - burgers, pizza, processed bread, fast food, etc. often appearing in the form of school lunch, as jeopardizing attempts to establish a healthy diet among family members. Mothers strived to regulate its appearance in the lives of their children, yet many also resigned to purchasing comida chatarra on occasion finding few other cheap and time-efficient options.

Women explained that management of the comida required careful discernment between foods perceived to bolster health and foods viewed as posing a health threat. In this way, comida could serve as

\footnotetext{
16 "La comida chatarra no me gusta. Peleo con él porque prefiero que se coma un plato de lentejas que una hamburguesa. Porque por ejemplo las hamburguesas se las comen en la escuela o les dan pizza. Pues yo prefiero que en mi casa, arroz con pollo, lentejas, un pedazo de pescado con ensalada."
} 
both the culprit - in the form of "chatarra" (junk) - and remedy - in the form of "saludable" (healthy) - for a variety of health problems, especially weight gain and diabetes, conditions that they suffered from personally or noted as common among family and friends. Mothers expressed concerns about the effects of eating a diet of comida chatarra and comida rápida: "They go buying something quick, perhaps for the reason of work. Eating this way, in large part, is what does them harm, makes them gain weight," ${ }^{17}$ (Juliana, 38, from Guerrero). Women also worried about how weight could trigger what was possibly a genetic disposition for diabetes, expressed by Pilar, 28, from Guatemala:

I feel unhealthy because I have gained a lot of weight. I feel a lot of tension about this, worry. I feel very bad. I've gained so much weight and I don't like it. I don't feel well, because [this weight] is doing me harm. I run the risk of raising my blood sugar, my father died of this... ${ }^{18}$

\section{Collective resistance: "cuidarnos en la comida"}

As illustrated by the above accounts, women noted several external and embodied changes associated with post-migration practices of eating and feeding. These changes could be conceptualized through a frame of 'postcolonial intersectionality' in which the imbricated layering of gender, race, class, and immigration status as markers of social difference had effects for one's access to resources and how such resources were managed.

Thus far, I have highlighted the multiple, intersecting political ecologies of food couched in a logic of neoliberal capitalism that reproduces the conditions of difference, imposes these conditions at the scale of the body, and attempts to manipulate affect and emotion. In terms of migrant women's relationship to food, this veritable biopolitics of 'food insecurity' has the effect of regulating women's access to foods, deterring them from seeking entitlements from the state, undermining attempts at food-based sociality, and exposing their bodies to harmful foods.

Yet the disciplinary mechanisms of this neoliberal capitalist logic are not completely totalizing in their effects. Women contest the unhealthy conditions of their environments and attempt to subvert differential modes of bodily governance that translate to disproportionate suffering. Zavella and Segura (2008) identify what they call 'subjective transnationalism' in observing how women in borderlands respond to the conditions of differential governance and enact an agentive negotiation of what it means to be a gendered subject in the borderlands and a contestation over the means of survival. I borrow from these authors' analytical framing in interpreting one mode through which migrant women grapple with the unevenness in food access and distribution that often exacerbates health and nutritional vulnerabilities. Specifically, I discuss the relevance of cuidarse en la comida to migrant women's navigation of constraints to "nourishing bodies and social ties," (Pérez and Abarca 2007:141) and to strategies of avoiding the development of unwanted pathologies. This practice of cuidarse en la comida also reveals how women act on the domain of social reproduction to connect generations (Counihan 2005), instill respect for elders, establish order and discipline, and pass on cultural narratives that connect younger generations to their heritage.

While women perceived comida chatarra as that which induced harm on the body in the form of enfermedades (illnesses) - "The junk food that one eats. This is what makes one sick" ${ }^{19}$ - they upheld a practice of "cuidarnos en la comida" (caring for ourselves through food) as a way of preventing illness and enabling the process of healing. Belen (23, from Guanajuato), for instance, a mother of two, had developed type-2 diabetes during pregnancy. She attributed this change in her body to dietary habits that were also responsible for her weight gain. In contrast, she linked her ability to manage her disease to a relinquishment of comida chatarra and more disciplined adherence to a diet of comida saludable (healthy food):

\footnotetext{
17 "Pues van comprando algo más rápido, tal vez por el tiempo del trabajo... porque muchas veces comen eh y a la largo eso les hacen daño se ponen gordos."

18 "[Me siento mal de salud] porque subí mucho de peso. Me siento con mucha tensión, preocupación. Me siento bastante mal...He subido mucho de peso y no me gusta. Y no me siento bien, porque me hace daño. Corro riesgo que se me suba la azúcar, mi papa murió de eso."

19 "La comida chatarra que come. Eso es lo que le hace mal."
} 
It's healthier to eat at home. My husband, my first child indulged me. I'd tell them "I feel like this, I feel like that [food]," I'd buy fast food. Since [the birth of] my daughter I didn't try to buy any [junk food]. As I said, this does harm to a person. My comadre ${ }^{20}$ told me [eating in the mode of chatarra] did me harm during my pregnancy and so I didn't buy it. Since I've stopped [eating chatarra], I've overcome my diabetes. $^{21}$

Belen continued to elaborate on the health habits she had cultivated since her most recent pregnancy. She heralded her own success with losing weight, which she explained was the result of reducing the quantity of bread and oil in her diet and by eating more fruits and vegetables:

I can't eat things like this, like pizza, for the reason that I'll develop diabetes and I don't want this. More fruits and vegetables is what helps one most, and for getting rid of diabetes. It can be hard but you have to avoid [these foods] in order to avoid diabetes. You can avoid sickness by eating healthfully. This is what I've tried to do, so when I think, "I want a piece of bread, I want a piece of pizza," I think first of my children. I say no, for my children's sake. Or else I'll get sick...and then what will happen to my children ${ }^{22}$

Women explained that avoidance of comida chatarra involved prioritizing meals that were cooked from scratch and prepared at home. Whereas chatarra typically indicated foods that originated from restaurants or commercial spaces outside the home, saludable denoted food prepared in the domestic sphere and usually demanded more time investment by women. Dora (35, from Honduras), for instance, attributed her weight gain to consuming a diet of pre-made fast and junk foods when she first arrived to the United States and began working as a hotel maid:

At night I'd go to work, and when I got hungry, I'd go out and buy something to eat. But yes, I feel that it did me a lot of harm because I got really fat. When I came [to the U.S.] I became very fat, overweight, I think 180 pounds [standing at 5 feet tall], but I was also eating all of this prepared food. ${ }^{23}$

Dora recalled a life-altering conversation on the phone with her mother in Honduras: "My mother said to me, 'You have to cook for your family, you shouldn't have to buy or eat food from the street. You have to know how to cook'." ${ }^{24}$ Since then, Dora had always followed her mother's advice of cuidarnos en la comida through nourishing her children with food that she herself prepared at home.

On the one hand, the practice of cuidarse en la comida could be interpreted as an effect of neoliberal capitalist logics of self-sufficiency and personal responsibility that increasingly transfer the onus for personal and familial health onto women, thereby reproducing the conditions of marginalization. Undoubtedly, there are clear benefits of this discourse and practice for advancing neoliberal capitalist projects. Yet on the other hand, we should not allow this interpretation to cloud the visibility of women's desires for and expressions of agency also conveyed through the discourse and practice of cuidnarse en la comida.

\footnotetext{
${ }^{20}$ A term used to address the mother of one's goddaughter or godson.

21 "Es más saludable comer en casa. Mi esposo, mi primer bebe me consentía mucho. Yo le decía tengo ganas de esto, tengo ganas de este otro, comida rápida me la compraba. De mi niña ya no le quise compra nada. Como dije esto ya le hace daño. Mi comadre me dijo todo me hace daño para el embarazo y ya no compraba. Yo me quedé, me salió el diabetes de mi embarazo."

22 "No puedo comer cosas así, cómo se dice la pizza, no puedo comer por lo mismo de que el diabetes se me desarrolle y no quiero eso... más frutas y verduras que es lo que ayuda más, abajar todo el diabetes. Es muy duro pero por no tener esa enfermedad puede evitar eso. Puede evitar la enfermedad comiendo saludable. Eso es lo que yo me temo, que pienso, "a pues quiero un pedazo de pan, quiero un pedazo de pizza," yo pienso primero en mis hijos. Digo no mis hijos, llego a pasar la enfermad...y este que van hacer mis hijos?"

23 "En la tarde me iba a trabajar y cuando me daba hambre pues me iba a comer, a comprar. Pero yo si, siento que me hacía daño porque yo me engordé mucho, muy gorda estaba. Cuando vine aquí me volví gorda, demasiado peso, yo creo unos de ciento ochenta libras, pero yo si comía mucha comida así comida comprada no cocinara."

24 "Mi mama me dice, 'Tienes que cocinarles a tu familia, no tienes que comprar ni comer tanta comida de la calle. Tienes que saber tu, cocinar."'
} 
Indeed, women who spoke of cuidarse en la comida heralded this practice as a site of social empowerment. Even though feminist scholars note how the linked act of caring and feeding contribute to women's subordination in the household (Barker 2005; Narotzky 1997), the binary nature of this labor, to at once enable women to appropriate kitchen space while also relegating them to a particular place within the household, stands as evidence of the need for feminist critique alongside recognition of women's expressions of agency (Rae 2008; Van Esterik 1999). By presenting themselves as engaged rather than withdrawn from the daily struggle (lucha diaria) of limited resources, these mothers conveyed a desire to resist and refuse the everyday structures of power that constrained them.

\section{Discussion}

The findings presented in this paper speak to the range of concerns traditionally associated with political ecological perspectives, namely conflicts over resources, challenges of environmental governance, and human-environment relationships. I have presented these findings in such a way as to underscore how 'the body' is a site - if not, the site - in which these concerns intersect, and promises itself as a highly useful analytic for tracing multiple, overlapping political ecologies of food in the context of women's transnational migration and 'bodies on the move.'

There are constraints on the resources that nourish bodies in one setting (Mexico and Central America) that precede the movement of women's bodies to another setting (the United States), at the same time that these women's bodies - particularly as essentialized 'emotional' or 'affective' bodies for the purposes of providing care and nourishment - are demanded by the United States labor market. Yet the structural components of the global food system that translate to the dispossession and nutritional vulnerability of rural households in various parts of Latin America, do not disappear once people from these communities decide to migrate to the United States. The agricultural sector in Santa Barbara County, as previously mentioned, primarily produced for a global market, thereby offering minimal, if any, promise for tackling local issues of 'food insecurity.' In other words, migrant women face constraints on reproductive labors at both 'ends' of this migration spectrum. In this regard, I have followed Heyman (2004) in looking at how human-environmental flows (in this case, via food) occur through paid and unpaid labor, consumption, and reproduction at the household level, and in wider contexts surrounding such households. I have advanced on his work by using a wider range of intersecting axes of inequality and power, by conveying the experiential as well as the material aspects of these processes, and by attending to embodiment, linked to the political ecology of health.

\section{Conclusion}

This article has provided evidence of the ways that food is both entangled with migrant women's motivations for migrating, and how it emblematizes livelihood struggles encountered by historically marginalized populations, especially people of informally authorized status in the United States. Although I argue that encounters with food scarcity, as an important aspect of the migration experience, have been generally ignored in the literature on migrant health and 'illegality,' my goal here has not been to reduce the entire migration experience to concerns with the everyday practices of eating and feeding. With that said, food represents one of the most direct relationships humans have with the natural environment, and thinking through food may help us to grapple with how our bodies are indeed a part of this environment. A biopolitics of food insecurity suggests that it is not only food that is governed through its production, distribution, and consumption, but also our bodies and how they are engendered (or not) through different political ecological processes.

I began by suggesting that a PEB framework could help to elucidate the ways that food insecurity is differentially distributed across populations, drawing attention to the ecological suffering of migrant women in particular. Political ecology as a field has helped us to clarify the ways in which environments are managed, and to recognize that 'healthy' environments are frequently co-produced alongside 'unhealthy' environments. My discussion of migrant women's experiences with the biopolitics of food insecurity provides insight into how unhealthy bodies do not necessarily index an ecological 'accident' within a logic of global capitalism. Although it is highly disturbing to contemplate such repercussions, we must not underestimate the potential for moral depravity that undergirds the engine of capital accumulation. 
In summary, a critical perspective on food insecurity views contemporary biopolitics, rather than individual failings, as responsible for colossal unevenness in access to vital resources. These biopolitics are visible in markets that stratify labor, and produce 'disposable' bodies preceding the conditions for food insecurity. They are also evident in the violence of state interpellations to 'food security' (Nally 2011). It is a biopolitics dictated by social constructions of belonging and deservingness, as well as racist, misogynist, and classist thinking, and thus calls for a 'postcolonial intersectionality' in its analysis.

\section{References}

Agamben, G. 1998. Homo sacer: sovereign power and bare life. Stanford: Stanford University Press.

Agustin, L.M. 2003. A migrant world of services. Social Politics: International Studies in Gender, State and Society 10(3): 377-396.

Baer, H. 1996. Toward a political ecology of health in medical anthropology. Medical Anthropology Quarterly 10(4): 451-454.

Barker, D.K. 2005. Beyond women and economics: rereading "women's work". Signs: Journal of Women in Culture and Society 30(4): 2189-2209.

Boehm, D.A. 2012. Intimate migrations: gender, family, and illegality among transnational Mexicans. New York: New York University Press.

Boris, E., and R. Salazar Parreñas. 2010. Intimate labors: cultures, technologies, and the politics of care. Stanford: Stanford University Press.

Brownell, S. 2005. Food, hunger, and the state. In J. Watson and M. Caldwell, (eds.) The cultural politics of food and eating: a reader. Malden, MA: Blackwell. Pp. 251-258.

Browner, C.H. and C.F. Sargent (eds.) 2011. Reproduction, globalization, and the state: new theoretical and ethnographic perspectives. Durham: Duke University Press.

Bryant, R.L. and S. Bailey. 1997. Third world political ecology. New York: Routledge.

Bureau of Population Statistics. 2010. Profile of general demographic statistics. Bureau of Population Statistics.

California Health Interview Survey. 2009. California Health Interview Survey.

Camarillo, A. 1979. Chicanos in a changing society: from Mexican pueblos to American barrios in Santa Barbara and Southern California. Cambridge: Harvard University Press.

Carney, M. 2011. "Food security" and "food sovereignty": what frameworks are best suited for social equity in food systems? Journal of Agriculture, Food Systems and Community Development 2(2): 71-87.

Carney, M. 2012. Compounding crises of economic recession and food insecurity: a comparison of three low income communities in Santa Barbara County. Agriculture and Human Values 29(2): 185-201.

Chang, G. 2000. Disposable domestics. Cambridge, MA: South End Press.

Chavkin, W., and J. Maher (eds.) 2010. The globalization of motherhood: deconstructions and reconstructions of biology and care. New York: Routledge.

Cleveland, D.A., et al. 2010. The 2010 Central Coast survey. University of California, Santa Barbara.

Cleveland, D.A. et al. 2011. The effect of localizing fruit and vegetable consumption on greenhouse gas emissions and nutrition, Santa Barbara County. Environmental Science and Technology 45(10): 45554562.

Coleman, M., and A. Kocher. 2011. Detention, deportation, devolution and immigrant incapacitation in the US, post 9/11. Geographical Journal 177: 228-237.

Colen, S. 1995. Like a mother to them": Stratified reproduction and West Indian childcare workers and employers in New York. In F. Ginsburg and R. Rapp, (eds.) Conceiving the new world order: the global politics of reproduction. Berkeley: University of California Press.

Counihan, C.M. 2005. The border as barrier and bridge: food, gender, and ethnicity in the San Luis Valley of Colorado. In A. Avakian and B. Haber, (eds.) From Betty Crocker to feminist food studies. Amherst, MA: University of Massachusetts Press. Pp. 200-217. 
Coutin, S. B. 2007. Nations of emigrants: shifting boundaries of citizenship in El Salvador and the United States. Ithaca: Cornell University Press.

De Genova, N. 2002. Migrant "illegality" and deportability in everyday life. Annual Review of Anthropology 31:419-47.

Fassin, D. 2011. Policing borders, producing boundaries: the governmentality of immigration in dark times. Annual Review of Anthropology 40: 213-226.

Gonzales, R.G., and L.R. Chavez. 2012. "Awakening to a nightmare": abjectivity and illegality in the lives of undocumented 1.5-generation Latino immigrants in the United States. Current Anthropology 53(3): 281.

Guthman, J. 2011. Weighing in: obesity, food justice, and the limits of capitalism. Berkeley: University of California Press.

Hayes-Conroy, J., and A. Hayes-Conroy. 2013. Veggies and visceralities: a political ecology of food and feeling. Emotion, Space and Society 6: 81-90.

Heyman, J.M.C. 1994. The organizational logic of capitalist consumption on the Mexico-United States border. Research in Economic Anthropology 15: 175-238.

- 2004. The political ecology of consumption: beyond greed and guilt. In S. Paulson and L. Gezon (eds.) Political ecology across spaces, scales and social groups. Newark: Rutgers University Press. Pp. 113132.

Himmelgreen, D., N.R. Daza, K. Cooper and D. Martinez. 2007. I don't make the soups anymore": pre- to post-migration dietary and lifestyle changes among latinos living in West-Central Florida. Ecology of Food and Nutrition 46(5-6): 427-444.

Holmes, S. M. 2012. The clinical gaze in the practice of migrant health: Mexican migrants in the United States. Social Science and Medicine 74(6): 873-881.

Holt-Giménez, E., and R. Patel. 2009. Food rebellions: crisis and the hunger for justice. Oakland: Food First Books. review

Horton, S., and J. C. Barker. 2009 "Stains" on their self-discipline: public health, hygiene, and the disciplining of undocumented immigrant parents in the nation's internal borderlands. American Ethnologist 36(4): 784-798.

- 2010. Stigmatized biologies: examining the cumulative effects of oral health disparities for Mexican American farmworker children. Medical Anthropology Quarterly 24(2): 199-219.

Housing Authority of Santa Barbara County. 2011. Income Limits.

Hubert, A. 2004. Qualitative research in the anthropology of food: a comprehensive qualitative/quantitative approach. In H. Macbeth and J. MacClancy (eds.) Researching food habits: methods and problems. New York \& Oxford: Berghahn Books. Pp.41-54.

IAASTD. 2009. Agriculture at a crossroads: international assessment of agricultural knowledge, science and technology. Global report. The United Nations.

Inda, J.X. 2002. Biopower, reproduction, and the migrant woman's body. In A. Aldama and N. Quinonez (eds.) Decolonial voices: Chicana and Chicano cultural studies in the 21st century. Bloomington: Indiana University Press.

Katz, S. 2008. Food to fuel and the world food crisis. Anthropology Today 24(1):1-3.

King, B. 2010. Political ecologies of health. Progress in Human Geography 34(1):38-55.

Larchanche, S. 2012. Intangible obstacles: health implications of stigmatization, structural violence, and fear among undocumented immigrants in France. Social Science and Medicine 74(6): 858-863.

Mankekar, P. 2002. 'India shopping': Indian grocery stores and transnational configurations of belonging. Ethnos 67(1): 75-97.

McMichael, P. 2009. A food regime genealogy. The Journal of Peasant Studies 6(1): 139-169.

Mendenhall, E. 2012. Syndemic suffering: social distress, depression, and diabetes among Mexican immigrant women. Walnut Creek: Left Coast Press.

Mollet, S., and C. Faria. 2013. Messing with gender in feminist political ecology. Geoforum 45: 116-125. 
Nally, D. 2011. The biopolitics of food provisioning. Transactions of the Institute of British Geographers 36: 37-53.

Narotzky, S. 1997. New directions in economic anthropology. London: Pluto Press.

Neumann, R.P. 2005. Making political ecology. New York: Hodder Arnold .

Parreñas, R. 2001. Servants of globalization: women, migration and domestic work. Stanford: Stanford University Press.

Peet, R., and M.J. Watts (eds.). 1996. Liberation ecologies: environment, development, social movements. New York: Routledge. ch.1

Pérez, R.L., and M.E. Abarca. 2007. Cocinas públicas: food and border consciousness in Great Mexico. Food and Foodways 15(3): 137-151.

Pérez-Escamilla, R., J. Garcia, and D. Song. 2010. Health care access among Hispanic immigrants: Alguien está escuchando? [Is anybody listening?]. NAPA Bulletin 34:47-67.

Plascencia, L. 2012. Disenchanting citizenship: Mexican migrants and the boundaries of belonging. New Brunswick: Rutgers University Press.

Quesada, J., L.K. Hart, and P. Bourgois. 2011. Structural vulnerability and health: Latino migrant laborers in the United States. Medical Anthropology 30(4): 339-362.

Rae, I. 2008. Women and the right to food: international law and state practice. Food and Agriculture Organization.

Rocheleau, D., B. Thomas-Slayter, and E. Wangari. 1996. Feminist political ecology: global issues and local experiences. New York: Routledge.

Rosas, G. 2012. Barrio libre: criminalizing states and delinquent refusals of the new frontier. Durham: Duke University Press.

Sargent, C., and S. Larchanche. 2011. Transnational migration and global health: the production and management of risk, illness, and access to care. Annual Review of Anthropology 40: 345-361.

Singer, M. 2009. Introduction to syndemics: a systems approach to public and community health. San Francisco: Jossey-Bass.

Stephen, L. 2007. Transborder lives: Indigenous Oaxacans in Mexico, California, and Oregon. Durham: Duke University Press.

Van Esterik, P. 1999. Right to food; right to feed: right to be fed: the intersection of women's rights and the right to food. Agriculture and Human Values 16: 225-232.

Willen, S.S. 2007. Toward a critical phenomenology of "illegality": state power, criminalization, and abjectivity among undocumented migrant workers in Tel Aviv, Israel. International Migration 45(3): 8-38.

- 2012. Migration, "illegality," and health: mapping embodied vulnerability and debating health-related deservingness. Social Science and Medicine 74(6): 805-811.

Willen, S.S., J. Mulligan, and H. Castaneda. 2011. Take a stand commentary: How can medical anthropologists contribute to contemporary conversations on "illegal" im/migration and health? Medical Anthropology Quarterly 25(3): 331-356.

Zavella, P. 2011. I'm neither here nor there: Mexicans' quotidian struggles with migration and poverty. Durham and London: Duke University Press.

Zavella, P., and D.A. Segura (eds). 2007. Women and migration in the U.S.-Mexico borderlands: a reader. Durham: Duke University Press.

— 2008. Introduction: gendered borderlands. Gender and Society 22(5): 537-544. 